\title{
A Phenomenological Study on Turkish Language Teachers' Views on Characters in Children's Books
}

\author{
Oğuzhan Yılmaz \\ Correspondence: Oğuzhan Yılmaz, Turkish Education, Erzincan University, Erzincan, Turkey.
}

\author{
Received: January 6, 2016 Accepted: January 20, 2016 Online Published: February 22, 2016 \\ doi:10.11114/jets.v4i3.1284 URL: http://dx.doi.org/10.11114/jets.v4i3.1284
}

\begin{abstract}
One of the indirect functions of the books is to help children discern the good, the nice and the correct through characters or protagonists to be self-identified. This study is to reveal what Turkish language teachers think about the character traits in children's books. One of the qualitative methods, phenomonological design was used in the study. The sample of the study was composed of Turkish language teachers teaching in public schools in different regions through snowball sampling. The data of the study were collected from Turkish language teachers by means of standardized open-ended interview form. The data were first analyzed by the researcher through descriptive analysis and the answers to questions in the interview form were classified in two different ways. The data under these two categories were tested in terms of content and classified into code and themes. The results of the study showed that the teachers were not informed of the protagonists in children's books, their traits, expectations of child readers and local and international sources in this field.
\end{abstract}

Keywords: children's literature, child book, character, Turkish language teacher education

\section{Introduction}

One of the indirect functions of the books is to help children discern the good, the nice and the correct through characters or protagonists to be self-identified. In this process, Turkish languages teachers play a key role. However, no single specific study has been reported, which focuses on what Turkish language teachers to bring together children with characters in children's books think about the characters in children's books. Therefore, this study is to reveal what Turkish language teachers think about the character traits in children's books.

Generally speaking, like that in adult literature, character in children's literature is defined as "the personage depicted from the perspective of feeling, behavior, thought and passions in such literary works as novel, narrations and dramas (Püsküllüoğlu, 1994)" while the protagonist in the same manner is described as the leading character in novel, story, drama and so on (TDK, 2011)". In order to clarify the relation between character and protagonist, Sever states that "the protagonists that live experiences animate certain characters in each work (2008)."

Characters that are known as the persons, who lead, develop, form and finish the event with a world of feelings and thoughts in children's fiction books, have also an educative role (Karataş, 2014). Dayığlu (2000) claims that as far as children's book is concerned, "it would be extraordinary to write a child book, which connects child to life, without any educational concern in our country." Kavcar supporting Dayığlu (1999) stipulated that literary works play a key role in human values, social life and adoption of values required today and therefore these works are effective in leading man to the good and the nice in the society.

The number of those who point out that literature and specifically characters have an educative function is not limited to Dayığlu and Kavcar. Mosher (2001) alleges that literature is a factor in development of character and key player in one's life and that the books are a kind of opportunity to discover such teaching as moral knowledge, sense and action. In addition Almerico (2014) literature is a strong means of teaching and good literature would influence acquisition of basic moral values. Similarly, Klein Ezell, Ezell, Powell Stanley and Ezell Powell (2014) limiting themselves to children's literature, argue that quality child literature contains many moral notions and important values and today tales, stories and popular children books are shaped through character education principles. To illustrate, according to Smith (2002) "fiction is not to teach. Works on children's literature and textbooks are not read to develop characters but books indirectly shape humans characters, affect them and help them rethink". The researchers (Karatay, 2011a; Karatay, 2011b; Tyra, 2012) tried to explain that literature shapes man's character. 
Based on these references, it can be concluded that concerning the relation between literature, child book, character/protagonist and education, one of the most important properties that child book protagonists should have is "that the protagonist provides opportunity to the child to identify with him" (Sever, 1995). As is widely known, characters in children's books are always either negative or positive references for children (Mardi, 2006) Taking this fact into consideration, taking after a character in a positive sense will help the child to improve his behavior. In addition, the child will not only ameliorate his behavior but also see the relevant character as a friend and thereby start to understand the society and people thanks to this imaginative hero (Erdem, 2011), and have self-confidence (Zivtçi, 2006). Moreover, the child who makes imaginative friend with the protagonist of the story he reads will have the opportunity to develop his personality by analogy with the features of the protagonist and have an insight into what kind of problems he would encounter and how to behave in the presence of such problems thanks to that protagonist (Kırıtoğlu Özdil, 2011).

The choice of a protagonist is certainly an important subject in shaping behavior of the child, acquisition of reading habit, development of confidence and to some extent preparation for life. Teachers specifically Turkish language teachers have quite important roles in meeting child with the protagonists to be self-identified. The teacher that has already information into the content of the book should recommend books to children and be informed about the characters and their features. Since no single study has been reported on Turkish language teachers' views on characters in children's books, these studies are very limited as to what teachers think about the characters in these books and which characters are recommended. Although studies on the lack of teachers' knowledge in content of the books have been reported, no single study/studies exist(s) directly with regard to teachers' views on characters. It is even obvious when the relevant literature is examined.

In Maltepe's study (2009) on the competence of Turkish language teachers in selecting children's literature products, teacher candidates asserted that the protagonists in child books should be connected with real life and that it is not approvable that they have close relation with magic or witchcraft and that our own heroes should be in these books. In addition to Maltepe, Çetinkaya Edizer and Çelik (2011) in their study revealed that Turkish language teacher candidates have been influenced by the books whose protagonist is a child and who struggle. Besides, in the same study, teacher candidates classified the qualities of the protagonists by the word "lonely, beautiful, frank, self-sacrificing, brave, stare gazer, honored and honest".

Besides the works on Turkish language teacher candidates and the content of children's book, studies on pre-school education teachers related to content of the children's books have been reported. Öztürk Samur (2011) averred in his study on the ability of pre-school education teacher candidates to select quality children's literature books that protagonists should be realistic as revealed in the researches conducted by Maltepe (2009), Çetinkaya Edizer and Çelik (2011). In another study conducted by Erdoğan and Özdemir (2011), pre-school education teacher candidates, as a condition for the abovementioned findings, suggested that child protagonists should be in child books most. In addition, they maintained that these characters should have such qualities as "problem-solving, creative, inquisitor, hard-working, knowledgeable, respectful, happy, funny, curious and brave" that the children are to self-identify.

Along these researches, studies have been reported concerning directly the views of primary and secondary school children on child books. Tekşan, Acar and Yiğit (2011) in their study on 9-12 year group, found that "most children wanted to see in their books heroes that "know everything and all kind of information". On the other hand, extraordinary, flying and invisible, funny and bold heroes are some of the qualities that children want to see in the books. Erdem (2011) in his study on the heroes in the child books from primary school students perspective, found that the most favorable heroes of these students are snow white, Kaloghlan, Wimpy Kid, Nasraddin Hodja, Little Red Riding Hood. According to his study, primary school students found heroes in child book as "funny, amusing, brave, nice and decent". Unlike Acar and Yiğit, Tekşan (2011) affirmed that students preferred to see real-like characters rather than imaginary heroes in their books. Similarities exist between the studies since students want to see more heroes in the books. The most important point that separates the present study from others is that it focuses on the effect of the books on children. Children at the end of the research insisted that child book heroes improve their reading and imagination and learned such values as honesty, goodness and helpfulness.

It is also considerable how heroes in texts are imagined as well as the qualities of these heroes viewed by teacher candidates and children. In the study conducted by Gönen, Katrancı, Uygun and Uçuş (2011) on primary school students' child books, their content, pictures and physical features based on 100 child books, it was found that protagonists are especially smart, curious and warmhearted while supporting characters are kindhearted, helpful and malignant. These findings demonstrate that positive character quality is supported for child to self-identify. In the study where Tosunoğlu and Alamdar (2011) studied texts in primary school $6^{\text {th }}, 7^{\text {th }}$ and 8th graders Turkish language textbooks, parallel results with those of Gönen et al (2011) were found. In the study, it was discovered that most protagonists in fictional texts reflected behavior that could be taken as example, responded to the need of identification 
of children by leaving their own mark.

As is clear in the literature, in spite of the studies on the attributes of characters in child books, no single study has been reported on the views of Turkish language teachers on them. The present study is important in that it not only reveals the protagonists that the children self-identify with but also reflects ideas of Turkish languages teachers about child book protagonists. The study is to reveal two problems below:

1. What kind of characters/protagonists do Turkish language teachers think should there be?

2. Which kind of characters/protagonists do the Turkish language teachers recommend children and for what reason?

\section{Method}

\subsection{Research Design}

One of the qualitative research designs, phenomenological design was used in this study. This design is interested in the essence of phenomena which are known but which do not possess in-depth understanding (Yıldırım and Şimşek, 2011). It tries to describe "experiences of individuals regarding a phenomenon (Creswell, 2014)." Since the aim of the study is to assess the views of Turkish language teachers on the characters in child books, phenomenological design was preferred.

\subsection{Sample of the Study}

The sample of the study consists of Turkish language teachers teaching in state schools in different regions of Turkey, who were selected through snowball sampling technique. Snowball sampling technique is one of the goal-oriented sampling methods (Merriam, 2013). This technique involves participants that are appropriate for the criteria defined in the study (Patton, 2014). For the study, no number regarding the participants was determined therefore interview forms were sent to 24 participants but only 19 gave feed-back. Examining these 19 forms, it was thought that a considerable amount of data was collected and there was no need to recollect data. Out of 19 teachers of the study sample, 9 teachers are female while 10 of them are male. Their teaching experience is less than 10 years. All of the teachers have been taught children's literature in their bachelor's degree.

\subsection{Data Collection}

Prior to data collection, a teacher was contacted and through this teacher, others teaching in different regions were contacted. We then sent interview forms to their emails and they were informed through their cell phones about the procedure and interview forms already sent. Once the forms were sent back filled out, they were examined. One month later, three of the teachers who gave feed-back were interviewed face to face and one teacher was communicated online in order to check the reliability and the validity of the forms. These four interviews confirmed the validity of the data collected.

The data of the study were collected through standardized open-ended interview forms in order to reduce subjectivity and partiality as well as for the sake of efficient use in the studies where there is more than one interviewee (Yildirım and Şimşek, 2011). As Patton (2014) states, since this approach requires careful and thorough study of each question prior to interview, before standardized open-ended interview form was printed, interview questions were prepared after a complete examination of the relevant literature and were revised taking into consideration sub-problems. Finally these questions were examined by two specialists of the field.

Pilot scheme was conducted on 8 teachers from different public schools in order to ensure reliability and validity of interview forms. After this pilot study, partial changes were made in the questions in the forms and final version of the questionnaire with two items was obtained.

Semi-structured interview online was conducted as secondary data source on four teachers in the study sample. This is to view non-verbal statements of teachers and to interfere in problematic points encountered in data collection by means of questions. In such an interview, the researcher leads a speech related to a sub-topic or heading determined, makes questions to emerge and is free to create without diverting from the topic in question (Patton, 2014). Indeed, the idea of confirming the data obtained is another reason that lies in the semi-structured interview on the internet.

\subsection{Data Analysis}

The data were analyzed in two ways. The data obtained by means of standardized were first descriptively analyzed by the researcher, were classified as the opinion of teachers on the characters in children's books and those on the characters in children's books that teachers suggest children to read. These data in these two categories were encoded following content analysis. The codings obtained later were reread and combined under certain themes. This would allow us to gather arounf simiar data within certain notions and themes and interpret them as much as the reader 
understands (Yıldırım and Şimşek 2011, 227).

In a similar vein, analyzing the data of the semi-structured interview online, first written record of the data recorded was completed by means of recorder. These records were exposed to the same analysis as those obtained by standardized open-ended questionnaire.

In the whole study, during encoding, in order to avoid subjectivity, encoding reliability test was conducted, a part of the data were encoded by the researcher in different times and again at the same time period by the researcher and one qualitative research specialist alike. By this way, encoding reliability was tested. The coherence was found more than .80 in both encodings. This suggests a coherency between encodings. The data of the study were collected through standardized open-ended interview forms in order to reduce subjectivity and partiality as well as for the sake of efficient use in the studies where there is more than one interviewee. As Patton (2014) states, since this approach requires careful and thorough study of each question prior to interview, before standardized open-ended interview form was printed, interview questions were prepared after a complete examination of the relevant literature and were revised taking into consideration sub-problems. Finally these questions were examined by two specialists of the field.

Pilot scheme was conducted on 8 teachers from different public schools in order to ensure reliability and validity of interview forms. After this pilot study, partial changes were made in the questions in the forms and final version of the questionnaire with two items was obtained.

\section{Findings and Interpretation}

\subsection{Views of Turkish Language Teachers on Characters in Children's Books}

Only a small number of Turkish language teachers demand that characters in children's books should be able to improve their imagination. The teachers that think the reality is taught in image (T3), stating that secondary school students do not have a limit of imagery to be supported by extraordinary characters (T7, T16). While there are teachers stating the characters in the books should possess extraordinary attributes, most believe that the characters should be close to real ones and they should be chosen from the types seen in daily life. (T6, T8, T14). Teacher 11 in this respect opposes to the claim that the characters in children's books should own extraordinary attributes stating that "the characters in children's books should be selected from the types that we can see in daily life. The heroes could be animals, plants or inanimate objects but they should never be those we do not see in daily life. For example, monsters, ghosts or so should not be selected". Similarly, teacher 13 made an emphasis on the selection of the protagonists from the types we can see in daily life expressing that "the protagonists should not be imagery, instead they should be from one of us" Teacher 16 explains why other teachers are in favor of real-like heroes pointing out that "a hero free from extraordinary attributes, which could be seen in a grocery, greengrocer's, park, bus, would definitely give the message to the child".

Turkish language teachers are of the opinion that characters in the books should possess positive attributes (T7, T10). In this respect, teacher 15 qualified the characters in the books as those that are "in harmony with national and spiritual values, respectful for traditional family ties, see freedom as a philosophy of life, ground on justice and man, like to work, consider the importance of science, revering and mannerly". Teacher candidate 14 thinks that no place should be given to the inappropriate characters for the human model to be imitated in children's books. Teachers think so just because they believe that children will model them. As a matter of fact, teacher 1 supports the idea that "children have a tendency to model themselves with the protagonists in the books they read at whichever age they are" and therefore the characters should be designed or imagined accordingly. Similarly, teacher 16 pointed out that characters should have positive attributes and guide children in a way that they should self-identify stating "generally positive attributes of the protagonists should be in the foreground since the child who finds hero empathetic tends to model him, which means imitating him in a positive or negative way".

On the other hand, there are also teachers, though very few in number, that are of the opinion that not only positive but also negative attributes of the heroes should be shown to the child reader (T6). Teacher candidate 12 adduces that there are bad people in the world, too not onlu good ones thus the characters with positive and negative attributes should be dealt with at the same time. Likewise, teacher candidate 2 in favor of teaching positive and negative attributes of the heroes to children indicates that "the characters in children's books should be in the foreground with their positive attributes. They should never be Pollyannaish either considering the fluctuations in life. Children must not be taught only the good but they should also learn the bad and allowed to find the truth themselves".

Individual views have also been reported regarding the characters declared by Turkish language teachers: First of all, the protagonists should not be imagined versatile. Teacher candidate 10 saying "the characters fictionalised for children should have complex attributes in fact they need to be clear and understandable. The more complicated a character is, the more perplexed children become" expressed that versatile characters might confuse the mind of child reader. Another factor that would cause confusion in child's mind and lead to ambivalence in child is the number of 
protagonists in the narratives. Teacher 1 told that in a book that contains quite many heroes, there might be confusions and continued to say that "...in children's books, many heroes should not be narrated so that the child does not live ambivalence"

Another distinguishing feature that appears right after the interview with Turkish language teachers is that general attributes of the characters should not be discovered at first glance. "the child should not immediately understand that heroes have negative or positive characters. The author ought to take into consideration this point while writing the book. That is, the child should not know which hero is bad, which one is good the moment he starts to read the book. Sometimes, we can easily find what kind of characters the heroes have right at the beginning of a movie. I do not think it is good (T11)" said the teacher emphasizing the fictionality of the characters in order for the curiosity to continue in the fiction.

\subsection{The views of Turkish Language Teachers on the Characters in Suggested Child Books}

A certain number of Turkish language teachers gave negative answer to the question "Do you have a child book character to recommend secondary school children?". According to teacher 15, the reason lies in the fact that he has never studied a child book. To be able to help the children "I think it is best that some books should be examined in order to suggest children from different perspectives. I have so far never studied a child book" saying that he is unable to read child book. Teacher 9 confesses that he does not a book to recommend either and this results from lack of reading a lot. Some of the teachers that express they do not have child book characters to propose children search for the reasons in themselves while others refer to external factors. For example, teacher 16 says that he does not have a child book character to recommend children and the reasons is that there is no qualified literary work in children's literature and thus no hero. Also, the same teacher sees in his terms passivity of the heroes as another reason why he does not advocate a character.

While there are teachers that do not directly offer child book characters, there are also teacher candidates who offer a character but mention a book name or author name instead of a character and sometimes even confuse the auther name with the character name. For instance, teacher 8 confused the name of the author with the character's name when saying "one of the characters that I can suggest children is Edmondo de Amicis, author of the heart of a boy". In addition, teacher 12 mentions the books Alice in Wonderland and Andersen Fairy Tales as suggestions for child book characters and teacher 13 gives the name of the author Recep Sukru Apuhan as a character in child books, which are clear signs of being uninformed.

Apart from the teachers that do not defend a child book character for their students for some reason or other, there are also teacher candidates that talk about a child book hero and allege him to their students for some reason. Among these heroes, they suggested "Little Prince". Interestingly, teachers pronounce the name "Little Prince" for almost the same reasons. Teachers, who emphasize that "Little Prince" reveals different points of view between adults and children (T11), illustrate that "Little Prince" brings out misbehavior of the adults and the more he grows up, the more the children grow up, the more they lose their spirit (T6). As a result, "Little Prince" make it difference and awareness in the innocent world of the children (T10).

Teacher 11 on this point says that he suggests Little Prince to his students “...just because it is a character that allows children to see adults from a different perspective". Teacher 2, who recommends Little Prince as a child book protagonist but gives a different reason for his suggestion that "I would suggest Little Prince for child book hero because the students whose imagination is at a top level would certainly improve such an ability through this book." $\mathrm{He}$ adds that a student would improve his imagination by knowing Little Prince well.

Alongside the Little Prince, the hero that is mentioned most is "Enrico" imagined by Amicis. Turkish language teachers demonstrate that they suggest Enrico based on his favorable personality. Teacher 1 sheds light on positive attitudes of Enrico saying that "He is a character that affects every child positively who needs to be away from prejudices, aware of family and dependent on family, from whom each child learns something." Similarly, teacher 11 is of the opinion that Enrico is a hardworking, honest, unbiased, virtuous, well-behaved character therefore every child must model him.

Though not individually mentioned by Turkish language teachers, the heroes like Little Prince and Enrico are suggested students for their virtues like honesty, righteousness, diligence. One of these heroes is Kaoru. Kaoru is suggested by teacher 5 just because he is a determined child. Teacher 9 suggests the hero in the work of Kemalettin Tugcu, "There was once a village here", as "he is personality that has moved from the city to the village, set up a home in a deserted village, and brought hope to the afflicted land and advocated production and labor against ready-made consumption of the city". Turkish language teachers suggest heroes like Momo and Totoca or Toto in their terms for students to improve their imagination as well as other heroes depending on their favorable personal attributes (T2, T14). For instance, teacher 14 puts emphasis on imagination telling "Momo is important in that he shows the only wealth of children is their world of imagination". 


\section{Result and Discussion}

Most of the Turkish language teachers in this study advocated that child book characters should be selected from those that would be seen in daily life and opposed to the idea that such characters have extraordinary attributes. In Maltepe's study (2009) on Turkish language teachers, similar results were found. In his study, Turkish language teacher candidates maintained that it would not be appreciable to support child book characters with magic or sorcery. Likewise, Öztürk Samur in his study on pre-school education teacher candidates (2011) urged that child book heroes should be realistic while Tekşan, Acar and Yiğit (2011) in their study on 9-12 year old children books found that children unlike their teachers and teacher candidates wanted to see extraordinary heroes that can fly, are invisible and funny. Therefore, the present findings show that the views of teachers and teacher candidates distinguish from those of children about child book characters. This might mean children do not read the books they want willingly and satisfy their need of humor. According to the findings of the research, though teachers suggest child book characters seen in daily life and it would be advisable for children to understand real life and self-identify with those they would see in life, this might cause a hindrance in improvement of their imagery.

Another view of Turkish language teachers regarding child book characters is that the characters in the books should be presented with their favorable attributes to the reader. In the study, teacher 11 looks for characters that "are helpful, honest, and respectful and display exemplary behavior". However, a few stated characters, which have positive and negative attributes at the same time instead of idealized heroes, should be presented to the readers. The relevant literature puts forward that heroes must come front with mostly their positive attributes. In Maltepe's study (2009) Turkish language teacher candidates described heroes in child books as "nice, frank, self-sacrificing, patient, brave and honored". Similarly, Aynı şekilde Erdoğan and Özdemir (2009) in their research found that pre-school education teacher candidates alleged heroes should be "Problem-solving, researcher, creative, laborious, knowledgeable, happy, nice, curious, brave and affectionate".

As one consequence of this situation, Tosunoğlu and Alamdar (2011) in their study on the texts in $6^{\text {th }}, 7^{\text {th }}$ and $8^{\text {th }}$ grade coursebooks found that the heroes in fictional texts showed exemplary behavior and met the need of children to self-identify thanks to their manners and works. We should bear in mind that although the heroes with favorable attributes would be helpful to the children to model them, those completely idealized and which have no discouraging features would cause some problems for children. In addition, it is contradictory that Turkish language teachers are both in the opinon that heroes should be selected from daily life and think these heroes should have only positive attributes.

When it comes to the suggestion of Turkish language teachers for a specific child book character, a considerable number of these teachers either because of their ignorance or due to the quality of heroes in the books stated they could not advise a protagonist. Some who say they have a suggestion for children give a name of an author or title of the work or just confuse the name of the hero with that of author. It is thought-provoking that teachers, who would help children gain reading habit and love reading do not have a child book hero to suggest. This might result from the fact that teachers have not seen enough child books.

There are also Turkish language teachers that cite a child book hero apart from those who do not. These teachers suggest Little Prince and Enrico most as characters. The reason why they recommend Little Prince is to reveal difference of point of view between a child and an adult while it is to emphasize positive attributes that Enrico possess. At this point, the studies of Maltepe (2009), Erdoğan and Özdemir (2011) support this finding. Another reason why Little Prince is offered most by these teachers to child readers might be that this work is a cult in children' literature and the work is almost identified with the term children's literature.

Alongside Little Prince and Enrico, Turkish language teachers recited also Kaoru, Momo and Totoca as child book heroes. While they recited Kaoru just because it has positive attributes, they stated that Momo and Totoca would contribute to their world of imagination. Some interesting points are worth mentioning: Turkish language teachers are not informed about child book character except for some, which is problematic for Turkish language teachers who would establish a bond between reading and students. Another point is that the very few child book characters that teachers know do not possess any national identity or quality. It is therefore enthralling that Turkish language teachers are not able to offer child book heroes from their own land. Lastly, it is questionable whether the heroes suggested by teachers would be adopted by children. Erdem (2011) in his study on child book heroes from primary school students' perspective found that primary school students classified their most loved child book heroes as "Kaloghlan, Snow White, Wimpy Kid, Nasraddin Hodja, Little Red Riding Hood”. These findings show that Turkish language teachers are not well informed about the heroes that children follow.

In consequence, it is obvious that Turkish language teachers are not knowledgeable about child book heroes, their qualities, expectations of child readers and local and international sources. In order to solve such a problem, they need to see a good many books and study them in detail. 


\section{References}

Almerico, G. M. (2014). Building character through literacy with children's literature. Researach in Higher Education Journal, 26. 1-13.

Creswell, J. W. (2014). Research design (S. B. Demir, Çev.). Ankara: Eğiten Kitap Yayınları.

Çetinkaya, E. Z., \& Çelik, G. (2011). Türkçe öğretmen adaylarının çocukluk dönemlerinde okudukları kitaplar hakkındaki düşünceleri. 3. Ulusal Çocuk ve Gençlik Edebiyatı Sempozyumu içinde (s.817-824). Ankara: Ankara Üniversitesi.

Dayığlu, G. (2000). Çocuk kitaplarında eğitsellik. I. Ulusal Çocuk Kitapları Sempozyumu Bildirileri içinde (s.522-535). Ankara: Ankara Üniversitesi.

Erdem, A. (2011). İlköğretim öğrencilerinin bakış açısıyla çocuk kitaplarında kahramanlar. 3. Ulusal Çocuk ve Gençlik Edebiyatı Sempozyumu içinde (s. 613-620). Ankara: Ankara Üniversitesi.

Erdoğan, S., \& Özdemir, Z. (2011). Okul öncesi öğretmen adaylarının çocuk kitaplarında olmasını istedikleri özelliklere ilişkin görüşleri. 3. Ulusal Çocuk ve Gençlik Edebiyatı Sempozyumu içinde (s. 625-634). Ankara: Ankara Üniversitesi.

Gönen, M., Katranc1, M., Uygun, M., \& Uçuş, Ş. (2011). İlköğretim birinci kademe öğrencilerine yönelik çocuk kitaplarının, içerik, resimleme ve fiziksel özellikleri açısından incelenmesi. Eğitim ve Bilim, 36(60), $250-265$.

Karataş, E. (2014). Çocuk edebiyatında “karakter” kavramı. Muğla Sıtkı Koçman Üniversitesi Sosyal Bilimler Enstitüsü Dergisi, 33, 60-79.

Karatay, H. (2011a). Using literary works in character education. Turkish Studies, 6(1), 1398-1412.

Karatay, H. (2011b). Transfer of values in the Turkish and Western children's literary works: Character education in Turkey. Educational Research and Reviews, 6(6), 472-480.

Kavcar, C. (1999). Edebiyat ve eğitim. Ankara: Engin Yayınevi.

Kırıtoğlu, Ö. S. (2011). Miyase Sertbarut'un “Kapiland'ın kobayları” adlı yapıtıyla Christine Nöstlinger'in "Kim takar salatalık kralı" adlı yapıtın karakter çerçeveleri bakımından incelenmesi. 3. Ulusal Çocuk ve Gençlik Edebiyatı Seтроzуити içinde (s.411-422). Ankara: Ankara Üniversitesi.

Klein, E. C., Ezell, D., Powell, S. S., \& Ezell, P. S. (2014). Character education using children's literature, puppets, magic tricks and balloon art. International Journal of Humanities and Social Science, 4(14), 1-15.

Maltepe, S. (2009). Türkçe öğretmeni adaylarının çocuk edebiyatı ürünlerini seçebilme yeterlilikleri. Balıkesir Üniversitesi Sosyal bilimler Enstitüsü Dergisi, 12(21), 398-412.

Mardi, H. Ö. (2006). Çocuk kitapları resimlemede karakter yaratma. Yüksek Lisans Tezi, Doku Eylül Üniversitesi, İzmir.

Merriam, S. B. (2013). Qualitative research a guide to design and implementation (S. Turan, Çev.). Ankara: Nobel Yayınlar1.

Mosher, J. (2001). Children's literature and character devolopment. The Fourth and Fifth Rs, 8(1), 1-3.

Öztürk, S. A. (2011). Okul öncesi öğretmen adaylarının nitelikli çocuk edebiyatı eserlerini seçebilme yetkinlikleri. 3 . Ulusal Çocuk ve Gençlik Edebiyatı Sempozyumu içinde (s. 219-228). Ankara: Ankara Üniversitesi.

Patton, M. Q. (2014). Qualitative research \& Evaluation methods (M. Bütün, S. B. Demir, Çev.). Ankara: Pegem Akademi Yayınları.

Püsküllüoğlu, A. (1994). Arkadaş Türkçe sözlük. Ankara: Arkadaş Yayınevi.

Sever, S. (1995). Çocuk kitaplarında bulunması gereken yapısal ve eğitsel özellikler. ABECE Eğitim, Ekin ve Sanat Dergisi, 107, 14-15.

Sever, S. (2008). Çocuk ve edebiyat. İzmir: Tudem Yayınları.

Smith, C. B. (2002). Developing character through literature. Bloomington: The Family Learning Association.

Tekşan, K., Acar, F., \& Yiğit, M. S. (2011). Çocuk edebiyatı eserlerine çocukların penceresinden bakış. 3. Ulusal Çocuk ve Gençlik Edebiyatı Sempozyumu içinde (s.937-946). Ankara: Ankara Üniversitesi.

Tosunoğlu, M., \& Alamdar, S. G. (2011). İlköğretim 6-8. sınıf Türkçe ders kitaplarında yer alan metinlerin içeriksel olarak çocuk edebiyatı nitelikleri açısından incelenmesi. 3. Ulusal Çocuk ve Gençlik Edebiyatı Sempozyumu içinde (s. 155-164). Ankara: Ankara Üniversitesi. 
Türk, D. K. (2011).Türkçe sözlük. Ankara: Türk Dil Kurumu Yayınları.

Tyra, C. (2012). Bringing books to life: Teaching character education through children's literature. Rising Tide, 5, 1-10.

Yıldırım, A., \& Şimşek, H. (2011). Sosyal bilimlerde nitel araştırma yöntemleri. Ankara: Seçkin Yayıncılık.

Zivtçi, F. (2006). Çocuk kitaplarında kahramanın yeri ve önemi. 2. Ulusal Çocuk ve Gençlik Edebiyatı Sempozyumu içinde (s. 245-247). Ankara: Ankara Üniversitesi.

This work is licensed under a Creative Commons Attribution 3.0 License. 